\title{
Evaluation to the Practice of Murabahah in the Operations of Baitul Mal Wattamwil (BMT), Yogyakarta $^{*}$
}

\author{
Oleh: Nur Kholis ${ }^{* *}$
}

\begin{abstract}
Abstrak
Riset ini merupakan analisis tentang konsep murabahah sebagai salah satu instrumen pembiayaan dalam transaksi Islam dan pelaksanaannya di BMT, Yogyakarta. Tujuan riset ini adalah (1) mengevaluasi praktik pembiayaan murabahah, baik prosedur dan pelaksanaannya di BMT Yogyakarta dan selanjutnya dievaluasi kesesuaian atau tidaknya prosedur dan pelaksanaan pembiayaan murabahah tersebut dengan prinsip-prinsip Syariah. (2) mengevaluasi cara penentuan margin keuntungan dalam kontrak murabahah di BMT Yogyakarta, apakah sama atau berbeda dengan

*Artikel ini merupakan modifikasi dari makalah/paper penulis yang pernah dipresentasikan dalam the First International Conference on Inclusive Islamic Financial Sector Development: Enhancing Islamic Financial Services for Micro and Medium Sized Enterprises (MMEs) di Empire Hotel and Country Club, Brunei Darussalam. Acara berlangsung antara 17 - 19 April 2007. Penulis mendapatkan kesempatan presentasi pada hari pertama conference, yaitu pada tanggal 17 April 2007.

${ }^{*}$ Head of Islamic Economic Department, Faculty of Islamic Studies, Islamic University of Indonesia, Yogyakarta, for period 2006-2010. Address: Islamic Economic Department, Faculty of Islamic Studies UII Jl. Kaliurang Km 14,5 Yogyakarta 55584 Phone: +62274-898462, Fax.: +62274-898463, Mobile: +62-8156883480, Email: nurkholis@fiai.uii.ac.id or nur kholisyes@yahoo.com
\end{abstract}


Nur Kholis: Evaluation to the Practice of ...

penetapan tingkat bunga di bank konvensional. (3) mengevaluasi sikap dan tindakan pihak BMT apabila terjadi default payment oleh nasabah sesuai waktu yang telah ditetapkan. Riset ini merupakan riset kualitatif yang mengaplikasikan theoretical and empirical methods. Metode analisis reflective thinking dengan kombinasi pola pikir deduksi, induksi dan komparasi diaplikasikan sebagai metode analisis. Hasil riset menunjukkan bahwa mayoritas aspek praktik pembiayaan murabahah di BMT Yogyakarta sesuai dengan Syariah.

Keywords: evaluation, operation, murabahah, BMT.

\section{Introduction}

\section{A. Background}

The development of Islamic finance (banking) in Indonesia, it has been spectacular recently. There are four types of Islamic or Syariah banks in Indonesia. They are Islamic commercial banks (BUS), Islamic banking units (UUS), Islamic rural banks (BPRS), and Islamic microfinance institutions (BMT). Bank Muamalat Indonesia (BMI) as the first Islamic commercial bank established in 1991 represents the first kind. Eight years later (1999), the second Syariah commercial bank was established, namely Bank Syariah Mandiri. Until November 2006, there are three Islamic commercial banks. ${ }^{1}$ The later Islamic commercial bank is Bank Syariah Mega Indonesia (2004). ${ }^{2}$

After the New banking Act (No. 10, 1998) had been regulated, many conventional banks are interested to operate the special branches which based on the Syariah law, named by Islamic windows or Islamic banking unit, for example Bank IFI Syariah branch (1999), Bank Jabar Syariah branch (2000), Bank BNI 46 Syariah (2000), Bank Bukopin Syariah branch (2001), BRI Syariah (2001), Bank Danamon Syariah (2002), BII Syariah (2003) etc. They operated dual banking system in their banking system. Until November 2006, there are 19 Islamic banking units. ${ }^{3}$

The third type is Syariah People's Credit Bank as Syariah rural banks. November 2006, there are 105 Syariah rural banks in Indonesia. ${ }^{4}$ The fourth type is Islamic microfinance institutions named Baitul Mal wat-Tamwil (BMT). BMT is an Islamic micro-finance institution, established by individual or group initiatives to help micro-entrepreneurs as a strategy for eradicating rural poverty, ${ }^{5}$

${ }^{1}$ Direktorat Perbankan Syariah Bank Indonesia (Nov 2006), Islamic Banking Statistic. (Jakarta: Bank Indonesia), p. 2.

${ }^{2}$ Direktorat Perbankan Syariah Bank Indonesia (2005), Laporan Perkembangan Perbankan Syariah Tahun 2005. (Jakarta: Bank Indonesia), p. 16.

${ }^{3}$ Direktorat Perbankan Syariah Bank Indonesia (2005), op.cit., p. 2.

${ }^{4}$ Ibid, p. 2.

${ }^{5}$ It is related with a research done by Saad al-Harran in Malaysia that published in 
especially in villages or traditional markets, operationally based on Syariah principles and cooperation. ${ }^{6}$ This research is focusing to this type of Islamic finance.

BMT is needed by the society of Indonesia because of these rationals, namely: (1) There are more than 34,8 millions micro-enterpeneur in Indonesia. ${ }^{7}$ (2) There are just a few banks having good attention and having willingness to connect directly with micro-enterpeneurs. Factually, these banks which have good attention and willingness to connect directly with micro-enterpeneurs emphasize getting high profit so that is precisely inflicted a loss upon the microenterpeneurs.

Recently, there are more than three thousands BMTs in the country. ${ }^{8}$ About 65 BMT's of them are located in Yogyakarta. There are only 42 BMT which reported their performance to PINBUK Yogyakarta regularly.

Founding of these Syariah micro-finance institutions obviously are not in line with the the society's understanding toward Islamic banking concept. Findings of DPNP-BI's research (Direktorat Kajian dan Pengaturan Perbankan Bank Indonesia) in cooperation with three universities in Java (Universitas Indonesia, Institut Pertanian Bogor, Universitas Brawijaya) 2000 show that frequently misunderstanding happened about Syariah banking concept. About $94 \%$ of 4000 respondent whom explained about Islamic banking system acknowledged that profit and loss sharing system is a universal system and can be accepted by all because of it's characteristic giving profit as well as to the bank and bank's customer. Society's consciousness to Islamic banking existence is relatively high $(79 \%){ }^{9}$

However their understanding about characteristic and uniqueness of Islamic banking products is very low. In fact even there is society's suspiciousness and unsatisfaction toward the existence of Islamic banking, they assumed that Islamic banking is same with conventional banking ( $10.2 \%$ of 1,500 respondent). They also assumed that mark price in murabahah contract was same with interest in conventional bank (16.5\% of 1,500 respondent). ${ }^{10}$

book format, namely Saad al-Harran et al. (1994), Islamic Marketing Strategy Eradicating Rural Poverty in Malaysia. (Selangor: Pelanduk Publication).

${ }^{6}$ PINBUK (t.t.), Pedoman Cara Pembentukan BMT. (Jakarta: Pusat Inkubasi Bisnis Usaha Kecil (PINBUK)), p. 2.

7 See Robert Rice (2004), "The Contribution of Household and Small Manufacturing Establishment to The Rural Economy”, in Thomas R. Leinbach (ed.) (2004), The Indonesian Rural Economy, Mobility, Work and Enterprise. Pasir Panjang Singapore: Institute of Southeast Asia Studies, p. 79.

${ }^{8}$ PINBUK dan www.bmtlink.web.id, accessed at 18 November 2006

${ }^{9}$ Bank Indonesia (2000), Potensi, Preferensi dan Perilaku Masyarakat terhadap Bank Syariah di Pulau Jawa. (Jakarta: Direktorat Penelitian dan Pengaturan Perbankan).

${ }^{10}$ According to Jafril Khalil, murabahah mode of financing offered by islamic 
Nur Kholis: Evaluation to the Practice of ...

Society's suspiciousness and unsatisfaction toward the existence of Islamic financial institution, maybe occurred because of their experience or their observation when they interacted with Islamic financial institutions (especially BMT) that they did not compliance to Syariah rules and regulation consistently yet. Even the findings of Magister Studi Islam UII's research showed that the recruited staff of BMT in Yogyakarta did not have any experience and knowledge how Islamic financial institution operated. ${ }^{11}$ So, it is assumed that there were operations of BMT in Yogyakarta not in line with Syariah rules. ${ }^{12}$

Based on these realities, it is very important to purify the BMT's operation so that in line with Syariah rules consistently. ${ }^{13}$ Murabahah product elected as an analyzed financing product because the portfolio proportion of murabahah financing product operated by BMT was more than others. ${ }^{14}$ So, it is assumed that murabahah instrument had heavy contribution to build negative opinion and assumption to society.

Yogyakarta elected as research location based on the rationales :below

1. Yogyakarta is the center of Muhammadiyah mass organization, and Muhammadiyah was being pioneer of BMT establishment in Indonesia. ${ }^{15}$

financial institution is rather similar with leasing product offered by conventional bank, even the equivalent rate of murabahah contract is higher than leasing product offered by conventional bank. So, it can be concluded that the Syariah banks don't want to bearing any risk. All risk are insurable to other party. See http://www.modalonlinecom/mod. php?mod=publisher\&op, accessed at 29 October 2004. It is considered as the main problem of contemporary islamic banking, so much so that it can be characterized as a crisis of identity for the Islamic financial system.

${ }^{11}$ Researcher Team Magister Studi Islam Universiti Islam Indonesia (MSI UII) (2004), Profesionalisme Praktisi BMT di Kota Yogyakarta dan Kabupaten Sleman. Yogyakarta: MSI UII, pp. 50-51.

12 Amir Mu'allim (2003), "Persepsi Masyarakat terhadap Lembaga Keuangan Syariah”, Jurnal al-Mawarid, Edisi X, 2003, p. 19; Muhammad (2002), Manajemen Bank Syariah. (Yogyakarta: UPP AMP YKPN), p. 4.

${ }^{13}$ Amir Mu'allim (2003), op.cit., p. 21.

${ }^{14}$ According to Abdullah Saeed, This phenomena is considered as a pragmatic model of Islamic banking and finance that being a weekness of Islamic banking and finance to reach their main objectives. See Abdullah Saeed (2004), "Islamic Banking and Finance, In Search of a Pragmatic Model”, dalam Virginia Hooker et al. (eds.), Islamic Perspectives on The New Millennium. (Singapura: Institute of Southeast Asian Studies), pp. 120-123.

${ }^{15}$ M. Dawam Rahardjo (2004), "Menegakkan Syariat Islam di Bidang Ekonomi”, foreward of Adiwarman Karim book, Bank Islam, Analisis Figh dan Keuangan. (Jakarta: PT RajaGrafindo Persada), p. xxii; Soertiana Nitisoemantri (2000), "Muhammadiyah dan Perkembangan Mu'amalah Kontemporer", in Muhammad Azhar et al. (eds.), Pengembangan Pemikiran Keislaman Muhammadiyah: Purifikasi dan Dinamisasi. 
2. Muhammadiyah was famous with it's purification movement of Islamic teachings.

3. Yogyakarta is located in the central of Java island. This geografic position makes Yogyakarta as a strategic town for many aspects like trade, education, culture, etc.

\section{B. The Problem Statements}

The research problems of this research are the following problems:

1. How do procedures of murabahah financing in BMT Yogyakarta applicated? Are the procedures and their application in line with Syariah rules?

2. How do murabahah profit margin determined? What are the similarities and differences of profit margin determination and interest rate determination in conventional bank?

3. What are the BMT management's policies and actions to solve default payment occurred in a financing product?

\section{Objectives}

This research is aimed at achieving the following objectives:

1. evaluation to the practice of murabahah financing products, its procedures and its application in the BMTs, Yogyakarta, Indonesia. The practices of them will be analyzed by Syariah's rules to prove its compliance to it or not

2. evaluation to mark up price method of murabahah financing product to show its similarities or differences with interest rate determination in conventional bank and to show its compliance to Syariah's rules or not

3. evaluation to the policies and actions of BMT's management if default payment by client occured. The practice of the policies and actions of BMT's management to the default payment case will be analyzed by Syariah's rules to prove its compliance to it or not.

\section{Contribution}

It is expected that the research findings contribute the followings:

1. To give the true explanation to the society about the real operation of murabahah financing in BMT Yogyakarta. It will be an answer to the society's negative opinion and prejudice to the operation of BMT's financing.

2. To assist the BMT management to advance their financing performance

3. Policy recommendations to support the existence and growth of BMT's

(Yogyakarta: LPPI UMY dan Majlis Tarjih Muhammadiyah), pp. 77-84. 
Nur Kholis: Evaluation to the Practice of ...

4. To assist the BMT management to enhance their product through its attributes.

\section{The Prior Research}

This section tries to seek and review the existence literature, particularly in relation to previous research conducted about the topic studied in this research. This is important in the context of the whole research in order to establish and/ or to guide the researchers to develop such a research hypothesis.

Perhaps, because of its new existence and unique form and operation in nature, there is only limited number of previous researches conducted for this topic. They are explained below:

Habib Ahmed ${ }^{16}$ wrote an article "Financing Microenterprises: An Analytical Study of Islamic Microfinance Institutions". It is about theoritical basis, operational framework, and empirical support for the establishment of Islamic Microfinance Institutions. Before presenting Islamic Microfinance Institutions as a good alternative of microfinance institution model, he evaluated the conventional microfinance institutions. According to some recent studies, there were many facts point out the failure of the conventional microfinance institutions in meeting some of their objectives. Some of the problems identified are (1) asymmetric information problems, (2) economic viability of the conventional microfinance institutions, (3) low rate of return on investment, (4) high drop out rate and non graduation from poverty, (5) debt trap, (6) targetting woman as recipient.

After critically evaluating the conventional microfinance institutions, he presented Islamic microfinance institutions as a good alternative of microfinance institution model. He wrote that theoritically there is a great potentiality of Islamic Microfinance Institutions that can cater for the needs of the poor. Islamic Microfinance Institutions have some inherent characteristics that can mitigate some of problems faced by conventional microfinance institutions. Empirical evidence from three Islamic Microfinance Institutions operating in Bangladesh, in general, supports some of theoritical assertions. The case studies, however, reveal that Islamic Microfinance Institutions have not yet tapped some of the sources of funds, nor have they used the variety of financial instruments in their operations.

Fuad Abdullah Omar dan Munawar Iqbal, ${ }^{17}$ wrote an article "Some Strategic Suggestions for Islamic Banking in the 21st Century”. He critically

${ }^{16}$ Habib Ahmed (2002), "Financing Microenterprises: An Analytical Study of Islamic Microfinance Institution”, Islamic Economic Studies, Vol. 9, No. 2, pp. 27-64.

${ }^{17}$ Fuad Abdullah Omar and Munawar Iqbal (2000), "Some Strategic Suggestions for Islamic Banking in the $21^{\text {st }}$ Century", Review of Islamic Economics, No. 9, pp. 37 56. 
evaluate the weakness of Islamic banking. They wrote that murabahah, one of the popular financing mode applicated by Islamic banks, is a mode of financing characterized by predetermined return as in the case of interest. It is said to contain some element of risk, but all these risks are insurable and are actually insured against. The uncertainty or risk to which the business being so financed is exposed is fully passed over to the other party. A financial system built solely around this mode of financing can hardly claim superiority over an interest based system on grounds of equity, efficiency, stabililty, and growth. It is considered as the main problem of contemporary islamic banking, so much so that it can be characterized as a crisis of identity for the Islamic financial system.

He highlight that the fixed return modes of finance being used by Islamic financial institution are clearly distinguishable from interest based modes. Transactions of the former modes are always done through real commodities, while in the latter they carried out through inter-temporal exchange of money. $\mathrm{He}$ also highlight that nobody denies that murabahah is permissible mode of financing. He also admitted that murabahah is serving a useful purpose. However, several problems have been noted in the way it is being used. He suggested that serious attempts should be made to cleanse the quasi murabahah being practiced by some islamic financial institutions at present of undesirable features, to make it genuine murabahah.

Joni Tamkin bin Borhan ${ }^{18}$ explains bay' al-murabahah in Islamic Commercial Law. He highlight that the legality of a murabahah is not questioned by any of the jurists mentioned in the fiqh literature. In this regard this type of financing is unanimously agreed by them without any rejection. However, the use of murabahah transactions as a credit vehicle by the contemporary islamic financial institutions has been regarded with apprehension by some scholars like Siddiqi considered the financier operated murabahah mode earns a predeterminated profit without bearing any risk.

PINBUK had also conducted a study of development evaluation of Pondok Pesantren Cooperative (KOPONTREN) and BMT. The study was conducted based on the survey upon 24 BMTs and 30 KOPONTREN in three provinces, west Java, middle Java and east Java provinces. The study concludes that there three external factors which possibly support the existence of KOPONTREN and BMT. They are (1) the consciences and willingness of muslims to utilize and assist the Islamic financial institutions. (2) KOPONTREN and BMT basically serve the customers well, both in delivering the products or services, and collecting the customers obligation; (3) KOPONTREN and BMT provide the easy procedures to get the finance projects.

Besides the supporting factors, the research also found some external

${ }^{18}$ Joni Tamkin bin Borhan (1998), "Bay" al-Murabahah in Islamic Commercial Law”, Jurnal Syariah, Bil 6, Januari 1998, pp. 53-58. 
Nur Kholis: Evaluation to the Practice of ...

obstacles. They are (1) the lack of knowledge of society toward BMT, as well as (2) misunderstanding among the part of society about the social and religious role of KOPONTREN and or BMT. (3) It is also found that basically there is no leading competitive commodity that can be financed; (4) KOPONTREN and BMT at most are lack of supervision and development assistance; (5) there is no single institution which can provide guarantee in the case of liquidity problem.

Amir Mu'allim ${ }^{19}$ explained that the problems faced by BMT are the existence of society prejudice toward operations of BMT that are not in line with Syariah rules. It caused trust degradation of saver of BMT and saver candidate. $\mathrm{He}$ also stated that the development of islamic banking industry is very rapid but it doesnot accompanied by supported infrastructure like professional human resources available and legality infrastructure. This situation brings islamic banking in trouble in the future. He concluded that the complexity of problems faced by Islamic financial institutions, especially BMT, bring negative impact to the society trust toward Islamic financial institutions, especially BMT.

While a research conducted by Suhardin ${ }^{20}$ researched the acceptancy of the society toward the existence of BMT. A research conducted by Sholihin ${ }^{21}$ researched the behaviour of customers toward BMT. Other researchers about BMT are Patimatu Jahra ${ }^{22}$ and Elida Putri Nauli. ${ }^{23}$ Their findings can be summerized that although a minority of society did not accept well the existence of BMT, generally can be concluded that the acceptance of society toward BMT include its principles, basic concept, fasilities and services. The findings also show that the existence of BMT has big contribution to develop the microenterprises.

While a research conducted by Ahmad Dahlan ${ }^{24}$ resulted many findings, among them is a fact that BMT Mentari Bina Artha Tegal operates mudarabah muqayyadah $f i$ al-nisbah bi al-miyyah system, a system of nisbah calculation assumption fixed $2.5 \%$ of total financing. This mechanism similar to interest

${ }^{19}$ Amir Mu'allim (2003), op.cit., pp. 17-31.

${ }^{20}$ Suhardin (1999), "BMT Sebagai Lembaga Keuangan Alternatif Ummat (Studi tentang Penerimaan Masyarakat atas Keberadaan BMT MUI di Kabupaten Sleman DIY)", Thesis of Islamis Studies, Magister Studi Islam, Universiti Islam Indonesia (MSIUII), Yogyakarta.

${ }^{21}$ Sholihin (1999), "Perilaku Konsumen Terhadap Produk BMT (Studi Kasus di BMT Kharisma Magelang Jawa Tengah)”, Dissertation of Islamis Studies, MSI-UII, Yogyakarta.

${ }^{22}$ Patimatu Jahra (2002), "Profil Usaha BMT Ukhuwah di Kota Banjarmasin", Dissertation of Islamis Studies, MSI-UII, Yogyakarta.

${ }^{23}$ Elida Putri Nauli (2002), "Peranan Kepuasan dalam Merangsang Minat menjadi Nasabah pada BMT Bina Tijarah, Cilegon Banten”, Dissertation of Islamis Studies, MSIUII, Yogyakarta.

24 Ahmad Dahlan (2002), "Implementasi Pembiayaan Mudharabah di BMT Mentari Bina Artha Tegal (Studi Kasus Tahun 1996-2001)", Dissertation of Islamis Studies, MSI-UII, Yogyakarta. 
calculation. BMT management argued that this mechanism is allowed based on urf consideration and usual mechanism adopted from global economic trend. In addition, they argued that the nisbah calculation operated by BMT did not apply the ad'afan muda'afah in case of default payment, so that it is different from the interest concept.

Based on the literature review delivered, this research is different from previous researches conducted about BMT or murabahah financing. This research is done to analysis and evaluate comprehensively the the practice of murabahah mode of financing as an Islamic instrument and contract for micro and medium sized enterprises in the operations of Baitul Mal Wattamwil (BMT), Yogyakarta, Indonesia.

\section{Research Method}

To achieve the purposes of this research, researcher undertakes theoretical method as well as empirical method.

\section{A. Theoritical Method}

The theoritical method deals with the theory of al-murabahah financing in Islamic teaching (elaborated from al-Qur'an, al-Sunnah and Fiqh books), the concept al-murabahah financing implemented in BMT, Yogyakarta, and the history of BMTs development to provide financial products and services based on Syariah rules. To find all of these, researcher reach the needed information in library by studying al-Qur'an, al-Sunnah, fiqh books, Islamic economic books, journal articles, research papers, institution profile of BMT, etc. The researcher also use internet services to get the contemporary issues related to the research thema.

\section{B. Empirical Method}

The empirical method deals with the operation of murabahah financing in BMT Yogyakarta. The empirical research and the pactical side of the investigation is based on a field work was carried out in BMT, Yogyakarta. This method devided into three steps, sampling method, data collection method, and analysis method.

\section{Population, Sample and Sampling Method}

Population of the research is all BMTs in Yogyakarta which count to be 65 units. They spread to five districts in Yogyakarta. The development of BMTs in two districts, namely Sleman and Kotamadya Yogyakarta is more rapid than 
Nur Kholis: Evaluation to the Practice of ...

others. Population of BMTs in these two districts count to be 30 units. ${ }^{25}$ Due to limited time and budget, it is impossible to cover all BMTs in Yogyakarta. The only way to handle this problem is to pick some of them as sample.

Sampling method selected to this research is purposive sampling method. So, these two district will be research location target and the number of the sample is two BMTs chosen, namely BMT Al-Ikhlas (Kotamadya Yogyakarta), BMT Bina Ummah and BMT Dana Syariah (Sleman).

Determination of these samples is based on the rationales below:

a. BMT exists in Yogyakarta relatively have similarity in organization structure, various products and services, organizasional management pattern, and also establishment mechanism.

b. Despite the sample research can be done more rapid and efisien in information gathering, every sample can be elaborated comprehensically because the number of sample are not very much.

\section{Data Collection Method}

a. Documentation

Some data, such as age of BMT, total asset of BMT, return on asset, total financing delivered by BMT, will be acquired from secondary resources.

b. Questionnaire

A considerable number of open question will be sent to the BMT management and the chief of financing operator or their chosen staff. Total questions are 27 questions. These Questionnaires had been sent to the respondent two weeks before interview done.

c. Interview

Some supporting data need to be acquired directly from BMT management and financing operator by using structural type interview. This has to be done to clarify the datas gathered from the questionnaire. In other hand, it is needed to anticipate the different interpretation of data collacted by other methods. Interviewed persons are limited to the BMT management and the chief of financing operator or their chosen staff.

\section{Method of Analysis}

The number of BMT researched is 3 BMTs, meanwhile the number of the BMT managements and the chief of financing operators or their chosen staff is 8 persons. All datas gathered will be analysed by qualitative analysis with

${ }^{25}$ Interview with Edi Nofianto (Vice Executive Directur of Pusat Inkubasi Bisnes Usaha Kecil Daerah Istimewa Yogyakarta (PINBUK DIY) and he also being a head of division in Pusat Koperasi Syariah (PUSKOPSYAH) DIY), at 16 May 2005. Data was supported by Muhammad Ridwan (Executive Directur of PINBUK DIY). Lihat pula www.bmtlink.web.id, accessed at 18 November 2004. 
operating reflective thinking method. Deductive, inductive, and comparative thought pattern are applicated to this research. ${ }^{26}$

The deductive thought pattern will be implemented to analysis the application of murabahah financing in BMT Yogyakarta and the compliance of murabahah financing procedures and their application with Syariah rules. The inductive thought pattern will be implemented to analysis the BMT management's attitude and action to default payment and the BMT management's attitutude and action to the change of interest rate in the conventional bank. The comparative thought pattern will be implemented to analysis the determination method of murabahah profit margin in BMT Yogyakarta and the similarities and differences of profit margin determination and interest rate determination in conventional bank.

\section{Research Findings and Recommendations}

\section{Findings}

Researcher had analyzed many related data to this research to reach the research objectives. This research has found three findings, namely:

a. The most concept of murabahah financing product, its procedures (covered three phase namely: the beginning of financing phase, the period of financing phase, and phase of pasca financing) and its applications operated by BMT's sample, Yogyakarta are compliance to Syariah's rules. However, there was an operation of murabahah financing contract in BMT Dana Syariah that unfulfilled the rules and regulations of murabahah contract namely in transaction when BMT Dana Syariah gave financing to the client for goods like petrolium, onions, vegetables etc. BMT Dana Syariah and the client had binded murabahah contract whereas the goods as object of contract were not exist at the time of contract binded or the goods were not being the property of BMT Dana Syariah yet. According to Islamic muamalat law, the existence of the goods as the object of contract is one of the relus an regulations of murabahah contract. So, in this case, BMT Dana Syariah involved in fuduli transaction that according to the part of ulama, among them ulama Hanabilah, Syafi iyyah, dan Zahiriyyah is prohibited by Syariah.

b. Mark up price method as a method of profit margin determination of murabahah financing product in BMT Yogyakarta determined by negotiation between BMT's party and client party until they agree to conduct contract ('an taradin minkum). This method is compliance to Syariah's rules, even it resembles to what Rasulullah SAW practiced in trading transactions. This

${ }^{26}$ Noeng Muhadjir (1990), Metodologi Penelitian Kualitatif. (Yogyakarta: Rake Sarasin), p.109. 
Nur Kholis: Evaluation to the Practice of ...

research also find that many aspects of murabahah financing product practice are different with interest rate determination in conventional bank, although there are certain and limited aspects seem similar. Certain and limited aspects seem similar but actually different are listed below:

1) Profit margin calculation method operated by BMT, Yogyakarta, namely counted up maximum total price then distributed into how many times installment payment, is alike with profit rate calculation based on flat interest rate model.

2) Quantity of profit margin in murabahah contract operated by BMT, Yogyakarta influenced by quantity of period financing. The longer period of financing, the higher profit margin required by BMT. Although majority of ulama (Hanafiyyah, Hanabilah, Syafi'iyyah, and Malikiyyah) and contemporary muslim scholar for example Yusuf al-Qaradawi, Rafiq Yunus al-Misri, and Muhammad Uthman Syubair admitted that the seller is allowed to add the price higher from the normal price for trade contract payed by installment payment. It is required that the selling price must be stated clearly in the beginning of contract binded. Extrincically, it resembles to interest rate concept in credit loan at conventional bank that considered period of financing as the determined factor to the quantity of interest. However, actually there is a real different aspect between both murabahah financing operation and credit loan operation, namely in case of default payment occured, the client of credit loan will be penaltied, in contrary the client of murabahah financing disallowed to be penaltied. The price in the beginning of murabahah contract is the final price fixed until the end of installment payment finished.

3) The characteristic of profit margin resulted by murabahah contract is fixed return to BMT. Extrincically, it resembles with interest that it is fixed return for credit loan in conventional bank. However, actually there is a real different aspect between both murabahah financing operation and credit loan operation, namely in case of default payment occured, the client of credit loan will be penaltied, in contrary the client of murabahah financing disallowed to be penaltied. Another substancial different thing is profit reached by BMT is fixed until the end of contract but the profit reached by conventional bank influenced by the change of Base Lending Rate (BLR). So, the profit reached by conventional bank is different every month. In this case, the client did not know actually how much they should pay their debt. In contrary with the client in murabahah contract that they know exactly how much they should pay their debt.

The real different aspects between murabahah financing operation in BMT Yogyakarta and interest rate operation in conventional bank are listed below:

1) Mark up price method as a method of profit margin determination 
of murabahah financing product in BMT, Yogyakarta determined by negotiation between BMT's party and client party until they agree to conduct contract ('an taradin minkum). It is different from interest rate decision in credit loan operated by conventional bank that determined by keeping up with interest rate developed in financial market.

2) In case of default payment occured, the client of credit loan will be penaltied, in contrary the client of murabahah financing disallowed to be penaltied. The price in the beginning of murabahah contract is the final price fixed until the end of installment payment finished.

3) There is a real good in murabahah contract as an object of trade between BMT and the client, so the debt of the client to BMT occured because of the trade contract, in contrary to the debt of the client to conventional bank that occured because of a lending money contract. In other word, the fixed return modes of finance being used by Islamic financial institution are clearly distinguishable from interest based modes. Transactions of the former modes are always done through real commodities, while in the latter they carried out through inter-temporal exchange of money.

c. Analysis toward policy and action of BMT's management in case of default payment occured showed that the most policies and actions of BMT management are compliance to Syariah's rules. However, there was an policy and action BMT Dana Syariah management that penaltied the defaulter payment to pay $3 \%$ of agreed profit margin and operation charge of debt collecting for every debt collecting Rp 10.000,-. The penalty paymet or fine is being a part of BMT Dana Syariah's income. This attitude and action is prohibited by Syariah laws, because according to Syariah laws, the price in the beginning of murabahah contract is the final price fixed until the end of installment payment finished. In other hand, majority of Ulama and Islamic economic scholar that agreed to fined the defaulter of payent disallowed to make the penalty payment as a part of Islamic financial institution income. The penalty payment must be used to social interest (maslahah 'ammah). Even the Islamic Fiqh Academy announced a fatwa that penalteing the defaulter payment to pay a few of money or other cost is the same of interest concept application.

\section{Recommendations}

Based on the findings of this research, profit margin minimum in murabahah contract at BMT, Yogyakarta per year is $24-30 \%$ of total financing in BMT Bina Ummah, 30.6\% of total financing in BMT Al-Ikhlas, and 234\% of total financing in BMT Dana Syariah. Extrinsically, if it is compared by the rate of interest rate developed in conventional bank market, $17-20 \%$ per year, the profit margin minimum in BMT is higher than interest rate developed in conventional bank market. 
Nur Kholis: Evaluation to the Practice of ...

However, researcher advices to find strategic step to break down the high profit margin to make the Islamic microfinance institution more competitive in the future. It is because the society assume that Islamic financing profit margin must be lower than interest rate in conventional bank.

First step is following the strategy of Rasulullah SAW in trading. Rasulullah SAW explain truly the buying price of good and other cost to the buyer. Rasulullah also explains the profit asked, then determined the selling price. Actually this methode was actualized by BMT management, but why the selling price higher? To solve this case, it must be done by analysing the determined factors influenced the selling price. For example how much the recovery cost expensed by BMT for the item? How much profit margin required by BMT management? How much portfolio targeted by BMT management? etc. All of these factors must be analyzed totally to reach the competitive profit margin. The BMT management also have to enrich the quality of human resources so that the operation of BMT became effisien.

Based on the findings of this research, there was an operation of murabahah financing contract in BMT Dana Syariah that unfulfilled the rules and regulations of murabahah contarct namely the BMT Dana Syariah involved in fuduli transaction that according to the part of ulama, among them ulama Hanabilah, Syaf' iyyah, dan Zahiriyyah is prohibited by Syariah. The suggestion recommended for this case is changing the mode of contract (murabahah contract) to musyarakah contract so that the contracts are in line with Syariah.

The findings of this research also showed that there was an attitude and action BMT Dana Syariah management that penaltied the defaulter payment to pay $3 \%$ of agreed profit margin and operation charge of debt collecting for every debt collecting Rp 10,000.00. The penalty payment or fine is being a part of BMT Dana Syariah's income. This attitude and action is prohibited by Syariah laws. Even the Islamic Fiqh Academy announced a fatwa that penalteing the defaulter payment to pay a few of money or other cost is the same of interest concept application. So, to solve this case, researcher suggested that the penalty payment must be used to social interest (maslahah 'ammah) or BMT party stopped giving penalty to defaulter.

\section{REFERENCES}

Abdullah Alwi Haji Hassan (2003), "Konsep dan Peranan Baitulmal di Zaman Kegemilangan Islam”, dalam Nik Mustapha Hj. Nik Hassan (ed.), Ke Arah Pembangunan Baitulmal Kebangsaan. Kuala Lumpur: PPZ dan MAIWP, pp. 1-14.

Afzalur Rahman (1997), Muhammad: Encyclopedia of Seerah. Isnan et al. (terj.), Muhammad Sebagai Seorang Pedagang. Jakarta: Yayasan Swarna Bhumy. Agus Sabardi (1993), Manajemen Kewangan. Yogyakarta: UPP AMP YKPN. 
Nur Kholis: Evaluation to the Practice of ...

Ahmad Dahlan (2002), "Implementasi Pembiayaan Mudharabah di BMT Mentari Bina Artha Tegal (Studi Kasus Tahun 1996-2001)”, Disertasi Sarjana Studi Islam, Magister Studi Islam Universitas Islam Indonesia Yogyakarta.

Ahmed, Habib (2002), "Financing Microenterprises: An Analytical Study of Islamic Microfinance Institution", Islamic Economic Studies, Vol. 9, No. 2, Mac 2002, pp. 27-64.

Amir Mu'allim (2003), "Persepsi Masyarakat terhadap Lembaga Keuangan Syariah" dalam Jurnal al-Mawarid, Edisi X, Tahun 2003, pp. 17-31.

(2004), "Praktik Pembiayaan Bank Syariah dan Problematiknya" dalam Jurnal al-Mawarid, Edisi XI, Tahun 2004, pp. 184-195.

Asyqar, Muhammad Sulaiman al- (1998), "Bay' al-Murabahah kama Tajrihi al-Bunuk al-Islamiyyah", dalam Muhammad Sulaiman al-Asyqar et al., Buhuth Fiqhiyyah fi Qadaya Iqtisadiyyah Mu'asirah, 2 j. 'Amman: Dar alNafa'is, pp. 71-114.

Bank Indonesia (2000), Potensi, Preferensi dan Perilaku Masyarakat terhadap Bank Syariah di Pulau Jawa. Jakarta: Direktorat Penelitian dan Pengaturan Perbankan.

(2002), The Blueprint of Islamic Banking Development Indonesia. Jakarta: Bank Indonesia.

Chapra, M. Umer (2000), "Why has Islam Prohibited Interest? Rationale Behind the Prohibition of Interest", Review of Islamic Economics, No. 9, pp. 5-20.

Darir, al-Sadiq Muhammad al-Amin al- (1985) "al-Ittifaq 'ala Ilzam al-Madin al-Mu'sir bi Ta'wid Darar al-Mumatilah", Journal of Research in Islamic Economics (Jeddah), Vol. 3, No.1, pp. 111-112 (Arabic section).

DeLorenzo, YusufTalal (1997), A Compendium of Legal Opinions on the Operation of Islamic Banks. London: Institute of Islamic Banking and Insurance.

Elgari, Mohamed Ali (2003), "Credit Risk in Islamic Banking and Finance", Islamic Economic Studies, Vol. 10, No. 2, Mac 2003, pp. 1-25.

Elida Putri Nauli (2002), "Peranan Kepuasan dalam Merangsang Minat menjadi Nasabah pada BMT Bina Tijarah, Cilegon Banten”, Disertasi Sarjana Studi Islam, Magister Studi Islam Universitas Islam Indonesia Yogyakarta.

Fiyruzabadi, al- (1983), al-Qamus al-Muhit. Beirut: Dar al-Fikr.

Ghayati, Lashin Muhammad al-, "'Arbun (Earnest Money) Sale”, Journal of Shari 'a and Islamic Studies, Kuwait University, Vol. 10, No. 26, pp. 111152, August 1995.

Hammad, Nazih Kamal (1985), “al-Mu’ayyidat al-Syar'iyyah li Haml al-Madin al-Mumatil 'ala al-Wafa' wa Butlan al-Hukm bi al-Ta'wid al-Mali 'an Darar al-Mumatilah", Journal of Research in Islamic Economics (Jeddah), Vol.3, No.1, pp. 101-108 (Arabic section).

Hasanin, Fayyad 'Abd al-Mun'im (1992), Bay' al-Murabahah fi al-Masarif al- 
Nur Kholis: Evaluation to the Practice of ...

Islamiyyah. Kaherah: al-Ma'had al-'Alamy li al-Fikr al-Islami.

Heri Sudarsono (2004), Bank dan Lembaga Keuangan Syariab; Deskripsi dan Ilustrasi. Yogyakarta: EKONISIA.

Hertanto Widodo Ak. (1999), Panduan Praktis Operasi Baitul Mal Wat Tamwil (BMT), Bandung: Mizan.

Ibn Manzur, Abu al-Fadl Jamal al-Din Muhammad Ibn Mukarram (1954), Lisan al-Arab, 15 j. Kaherah: al-Dar al-Misriyyah li al-Ta'lif wa al-Tarjamah.

Jaziri, 'Abd al-Rahman al- (t.t.), Kitab al-Figh 'ala al-Madhahib al-Arba'ah, 4 j., c. 6. Kaherah: al-Maktabah al-Tijariyyah al-Kubra.

Joni Tamkin bin Borhan (1998), "Bay" al-Murabahah in Islamic Commercial Law”, Jurnal Syariah API UM, Bil 6, Januari 1998, pp. 53-58.

M. Amin Aziz (2000), "Prospek BMT Berbadan Hukum Koperasi", dalam Baihaqi Abd. Madjid dan Saifuddin A. Rasyid (ed.), Paradigma Baru Ekonomi Kerakyatan Sistem Syariah: Perjalanan gagasan \& Gerakan BMT di Indonesia, Jakarta: PINBUK, pp. 2-16.

M. Dawam Rahardjo (2004), "Menegakkan Syariat Islam di Bidang Ekonomi”, kata pengantar Buku Adiwarman Karim, Bank Islam. Jakarta: PT RajaGrafindo Persada, pp xiii-xxv.

Misri, Yunus Rafiq al- (1977), Masraf al-Tanmiyat al-Islami. Beirut: Mu'assasah al-Risalah.

Mohd. Ma'sum Billah (2003), Modern Financial Transaction Under Shari'ah. Petaling Jaya: Ilmiah Publishers Sdn. Bhd.

Muhammad Akhyar Adnan et al. (2001), Study on Factors Influencing Performance of The Best BMT in Indonesia. Jakarta: PT Redecon dan USAID.

Muhammad Ridwan (2004), Manajemen Baitul Mal Wattamwil (BMT). Yogyakarta: UII Press.

Noeng Muhadjir (1990), Metodologi Penelitian Kualitatif. Yogyakarta: Rake Sarasin.

Omar, Fuad Abdullah and Munawar Iqbal (2000), "Some Strategic Suggestions for Islamic Banking in the $21^{\text {st }}$ Century", Review of Islamic Economics, (Journal of The International Association for Islamic Economics). Leicester: The Islamic Foundation, No. 9, pp. 37-56.

Patimatu Jahra (2002), "Profil Usaha BMT Ukhuwah di Kota Banjarmasin”, Disertasi Sarjana Studi Islam, Magister Studi Islam Universitas Islam Indonesia Yogyakarta.

PINBUK (t.t.), Pedoman Cara Pembentukan BMT. Jakarta: Pusat Inkubasi Bisnis Usaha Kecil (PINBUK).

(1999), Kajian Evaluasi Pengembangan Koperasi Pondok Pesantren dan BMT. Jakarta: PINBUK dan DEPKOP

Qaradawi, Yusuf al- (1987), Bay'al-Murabahah li al-Amir bi al-Syira'kama Tajrihi 
al-Masarif al-Islamiyyah. t.t.p.: Maktabah Wahbah.

Rice, Robert (2004), "The Contribution of Household and Small Manufacturing Establishment to The Rural Economy", dalam Thomas R. Leinbach (ed.) (2004), The Indonesian Rural Economy, Mobility, Work and Enterprise. Pasir Panjang Singapore: Institute of Southeast Asia Studies, pp. 101-121.

Roni Hanitijo Soemitro (1982), Metodologi Penelitian Hukum. Bandung: Sinar Baru.

Saad al-Harran et al. (1994), Islamic Marketing Strategy Eradicating Rural Poverty in Malaysia. Selangor: Pelanduk Publication.

Saeed, Abdullah (2004), "Islamic Banking and Finance, In Search of a Pragmatic Model", dalam Virginia Hooker et al. (ed.), Islamic Perspectives on The New Millennium. Singapura: Institute of Southeast Asian Studies, pp. 113-129.

Sawi, Muhammad Salah Muhammad al- (1990), Musykilah al-Istithmar fi alBunuk al-Islamiyyah. Jedah: Dar al-Mujtama'.

Sholihin (1999), "Perilaku Konsumen Terhadap Produk BMT (Studi Kasus di BMT Kharisma Magelang Jawa Tengah)", Disertasi Sarjana Studi Islam, Magister Studi Islam Universitas Islam Indonesia Yogyakarta.

Soertiana Nitisoemantri (2000), "Muhammadiyah dan Perkembangan Mu'amalah Kontemporer", dalam Muhammad Azhar et al. (eds.), Pengembangan Pemikiran Keislaman Mubammadiyah: Purifikasi dan Dinamisasi, Yogyakarta: LPPI UMY dan Majlis Tarjih Muhammadiyah, pp. 74-86.

Sofyan S. Harahap dan Yuswar Z. Basri (2004), "The History and Development of Islamic Banking in Indonesia, 1990-2002", dalam Bala Shanmugan et al. (ed.), Islamic Banking: An International Perspective. Serdang: Universti Putra Malaysia Press, pp. 31-62.

Suhardin (1999), "BMT Sebagai Lembaga Keuangan Alternatif Ummat (Studi tentang Penerimaan Masyarakat atas Keberadaan BMT MUI di Kabupaten Sleman DIY)", Tesis Sarjana Studi Islam, Magister Studi Islam Universitas Islam Indonesia Yogyakarta.

Syubair, Muhammad Uthman (1998), al-Mu'amalat al-Maliyyah al-Mu'asirah $f i$ al-Fiqh al-Islami, Beirut: Dar al-Nafa'is.

Tim Peneliti Magister Studi Islam Universitas Islam Indonesia (MSI UII) (2004), Profesionalisme Praktisi BMT di Kota Yogyakarta dan Kabupaten Sleman. Yogyakarta: MSI UII.

Turkmani, 'Adnan Khalid at- (1981), Dawabit al-Aqd fi al-Fiqh al-Islami, Jeddah: Dar al-Syurq.

Zuhayli, Wahbah al- (1989), al-Figh al-Islami wa Adillatuh, 8 j. Beirut: Dar al-Fikr. 
Nur Kholis: Evaluation to the Practice of ...

\section{Websites}

http://www.bmtlink.web.id, diakses tanggal 18 November 2004.

http://www.alikhlas-group.com, diakses pada 19 April 2005.

http://www.jogja.com/index.php?folder=utama\&file=about.html, diakses pada 18 November 2004.

http://www.dijogja.com/tpldijogja.php?app=area\&p_area_id=id.diy\&bhs=ind, diakses pada 18 November 2004.

http://www.gatra.com/2003-12-13/artikel.php?id=32240, diakses pada 29 Oktober 2004.

http://www.modalonlinecom/mod.php?mod=publisher\&op, diakses pada 29 Oktober 2004.

http://republika.co.id/, diakses pada 20 Januari 2006. 